\title{
Prevalence and Incidence of Garlic (Allium sativum L.) Infecting Viruses in Ethiopia
}

\author{
Debebe $\mathrm{A}^{1 *}$, Mijena $\mathrm{D}^{1}$, Abrham $\mathrm{A}^{3}$, Aklilu S ${ }^{1}$, Asami $\mathrm{P}^{2}$ and Holton $\mathrm{T}^{2}$ \\ ${ }^{1}$ Ethiopian Institute of Agricultural Research, Ethiopia \\ 2Biosciences eastern and central Africa-International Livestock Research Institute Hub \\ (BecA-ILRI), Kenya \\ ${ }^{3}$ Addis Ababa University, Ethiopia
}

\section{Research Article \\ Volume 2 Issue 1}

Received Date: January 12, 2017

Published Date: January 24, 2017

*Corresponding author: Debebe A, Ethiopian Institute of Agricultural Research, Addis Ababa, Ethiopia, E-mail: aabbeelldebebe@gmail.com

\section{Abstract}

In Ethiopia, virus infection is among the most important cause for yield and quality loss in garlic production like other countries. Detection and identification of garlic viruses on fifty two samples which includes three improved varieties (Bishoftu nech, Tseday and Kuriftu) collected from different parts of Ethiopia was carried out in 2014 at BecA-ILRI hub, Nairobi, Kenya. The detection was carried out based on RT-PCR (Reverse Transcription polymerase chain reaction) using general potyvirus detection primers viz. $\mathrm{CP}, \mathrm{Nib}$ and specific primers for allexiviruses those had been designed from genome sequencing of Ethiopian infected garlic samples. The RT-PCR result showed that $85 \%$ and $80 \%$ of the samples were infected by potyviruses which are the most prevalent and commonly detected across the country. Moreover, three viruses from allexiviruses namely Garlic virus-b (56\%), Garlic virus-c (31\%) and Garlic virus-d (31\%) were identified with their level of incidences. Co-infection of potyvirus and allexiviruses were observed in all tested samples. This phenomenon has been reported by other researchers as well. The result depicted that the three improved varieties were completely infected by the viruses across all areas.

Keywords: Allexivirus; Carlavirus; CP-Coat protein; Degenerate primer; Nib-Nuclear inclusion protein; Potyvirus and RT-PCR

\section{Introduction}

Garlic (Allium sativum L.) is a very important medicinal and spice plant [1]. Though, world uses for different purposes bulbs of garlic harbour complex of virus due to its exclusive vegetative propagation which in turn results in yield and quality reduction about $50-70 \%[2,3]$. For instance, study result indicated that co infection of garlic planting material by potyvirus and allexivirus resulted in yield loss of up to $78 \%$ [4]. About twelve viruses which are found in three genera viz. potyvirus (family, Potyviridae), allexivirus (family, Alexiviridae) and carlavirus (family, Flexiviridae) have been identified as the main infection agents for garlic production in the world [5]. According to [6] Onion yellow dwarf virus (OYDV), Leek yellow stripe virus (LYSV) is the most common important viruses from potyvirus. All members of Potyviridae viruses have positive single strand RNA genome $\sim 10 \mathrm{~kb}$ in length. Whereas Garlic virus $A$ (Gar$\left.\mathrm{V}_{\mathrm{A}}\right)$, Garlic virus $B\left(\mathrm{Gar}-\mathrm{V}_{\mathrm{B}}\right)$, Garlic virus $\mathrm{C}\left(\mathrm{Gar}-\mathrm{V}_{\mathrm{C}}\right)$, Garlic 


\section{Open Access Journal of Agricultural Research}

virus $D\left(\right.$ Gar- $\left.V_{D}\right)$, Garlic virus $E\left(\right.$ Gar- $\left.V_{\mathrm{E}}\right)$, Garlic virus $X$ $\left(G a r-V_{X}\right)$, Garlic mite born filamentous viruses (G-Mb Fv) and Shallot virus $X\left(\mathrm{Sh}-\mathrm{V}_{\mathrm{X}}\right)$ were reported as the most prevalent species from allexivirus genus [6,7]. Allexivirus are mite-borne viruses and they have positive sense single strand RNA genome with different genome organization $\sim 9 \mathrm{~kb}$ in length (Fajardo et al., 2001). While, carlavirus comprises Garlic common latent virus (GCLV) and Shallot latent viruses (SLV) moreover potyvirus and carlavirus are aphid born viruses [8,9]. Ethiopia is one of the ten leading garlic producing country in the world (www. seriousrankings.com). It is the second most widely cultivated Allium in the country. According to [10] Adet, Ambo, Debere-work, Sinana, Jimma and other Ethiopian highlands are the main producer of garlic. Despite its importance garlic production has been seriously challenged by a biotic and biotic stress [11].

In Ethiopia, virus is one of the most important constraints like other counties in the world. However, very few information has been found on garlic infecting viruses in Ethiopia and there levels of incidences has not been addressed in the country [12] reported that co infection of five viruses from potyvirus and allexivirus had been identified using ELISA techniques. Yet RT-PCR garlic virus diagnosis using assay which are developed from Ethiopian infected garlic samples based on virus genome sequencing information has not been done so far. Thus, garlic infecting viruses identification and determination of their levels of incidence across the country based on RT-PCR techniques using coat protein gene targeting primers designed from genome sequence of the viruses will help to get efficient and successful virus identified system which intern will assist to get accurate information for cleaning and other management practices to produce healthy garlic planting materials and effective quality control platform in the country. Thus this experiment was initiated with the objectives of monitoring the prevalence and incidences of garlic viruses in Ethiopia using RT-PCR assay.

\section{Material and Methods}

\section{Planting Materials}

Garlic cloves of forty nine accessions and three improved varieties (Bishoftu Nech, Tseday and Kuriftu) collected from different parts of Ethiopia by Deber Zeit Agricultural Research Centre, Ethiopia were used for this study. Cloves were planted at BecA-ILRI, Nairobi Screen house in 2014. Fresh young leaves which showed yellowing, mosaic and stunting symptoms from thirteen days old seedlings were selected for RNA extraction.

\section{Reverse Transcriptase Polymerase Chain Reaction (RT-PCR)}

Total RNA was extracted from each sample using ZR plant RNA Mini Prep kits (www.zymoreserch.com) following the manufacturer instruction and the RNA quantity and purity were evaluated using Nano Drop Spectrophotometer. For the detection potyvirus two sets of general primer pairs designated as (CP and Nib) were used while for allexiviruses specific primer pairs which were designed from viral sequence information from Ethiopian samples were used (Table 1). The presence or absence of the expected amplicons of approximately $350 \mathrm{bp}$ and $520 \mathrm{bp}$ for potyviruses and $200 \mathrm{bp}, 400 \mathrm{bp}$ and $200 \mathrm{bp}$ for garlic virus $\mathrm{b}$, garlic virus $\mathrm{c}$ and for garlic virus $\mathrm{d}$ be will evaluated respectively.

\begin{tabular}{|c|c|c|c|c|}
\hline primer & Sequence $\left(5^{\prime}-3^{\prime}\right)$ & TA $\left({ }^{\circ} \mathbf{C}\right)$ & $\operatorname{TM}\left({ }^{\circ} \mathbf{c}\right)$ & $\begin{array}{l}\text { Exp. Amp } \\
\text { (bp.) }\end{array}$ \\
\hline \multicolumn{2}{|c|}{ Potyvirus-General } & & & \\
\hline $\mathrm{CP}_{\mathrm{For}}$ & TGG ACT ATG ATG GAT GGC GTG GA & \multirow{2}{*}{61} & 55.8 & \multirow{2}{*}{350} \\
\hline $\mathrm{CP}_{\mathrm{Rev}}$ & TGT GTG CCT YTC CGT GTC CT & & 57.9 & \\
\hline $\mathrm{Nib}_{\text {For }}$ & CCA AAA CTA GAT CAA GAG CG & \multirow{2}{*}{56} & 49.1 & \multirow{2}{*}{520} \\
\hline $\mathrm{Nib}_{\mathrm{Rev}}$ & TCG CCA TCC ATC ATA GTC C & & 52.7 & \\
\hline \multicolumn{2}{|c|}{ Allexivirus-specific } & & & \\
\hline GarVb $_{\text {For }}$ & TGA CGG GCA AAC AGC AGA ATA A & \multirow{2}{*}{56} & 59.1 & \multirow{2}{*}{200} \\
\hline GarVb $_{\text {Rev }}$ & ATA TAG CTT AGC GGG TCC TTC & & 51.2 & \\
\hline GarVc For & CTG TAG CCA CAC AGA GCA CA & & 51.6 & \multirow{2}{*}{400} \\
\hline $\mathrm{GarVc}_{\mathrm{Rev}}$ & CCC GAG AAT TTC TGC TTG CG & & 59.3 & \\
\hline GarVd $_{\text {For }}$ & TTA GCT TGG ACG TGC TAC CA & \multirow{2}{*}{58.5} & 53.2 & \multirow{2}{*}{200} \\
\hline GarVd $d_{\text {Rev }}$ & ACT GGC TGG TGG TTT CT & & 52.5 & \\
\hline
\end{tabular}

${ }^{*}$ Cp-designated coat protein, Nib- nuclear inclusion protein, GarVb-Garlic virus b, GarVc- Garlic virus c and GarVd- Garlic virus d, TA- annealing temperature, TM-melting temperature, Exp. amp-expected amplification.

Table 1: Primers pairs used for the amplification of the coat protein and Nib genes of Potyvirus and Allexivirus. 


\section{Open Access Journal of Agricultural Research}

\section{c-DNA synthesis}

First strand cDNA synthesis was performed following recommended procedure of Maxima $\mathrm{H}$ minus first strand cDNA synthesis kit (www.thermofisher.com).

\section{Polymerase Chain Reaction}

PCR for amplification of cDNA was performed with BIONEER PCR reaction mix with template DNA and the forward and reverse primer pairs for general potyvirus and specific primer pairs for garlic virus b, garlic virus $c$ and garlic virus d. The PCR profile was $94^{\circ} \mathrm{C}$ for $3 \mathrm{~min}, 30$ cycles $\left(94{ }^{\circ} \mathrm{C} 30 \mathrm{sec}, 61^{\circ} \mathrm{C}\right.$ for $1 \mathrm{~min}$ and $72^{\circ} \mathrm{C}$ for $1 \mathrm{~min}$ ) and final extension at $72^{\circ} \mathrm{C}$ for $7 \mathrm{~min}$ for general potyvirus primer and the same reaction with different annealing temperature (Table 1) for the specific allexiviruses. The PCR products were analyzed by Gel Electrophoresis with $1.5 \%$ Agarose gel run for $40 \mathrm{~min}, 100 \mathrm{volt}$.

\section{Result and Discussion}

The two pairs of general primers for potyvirus amplified the expected size of $350 \mathrm{bp}$ and $500 \mathrm{bp}$ for positive samples (Figure 1).

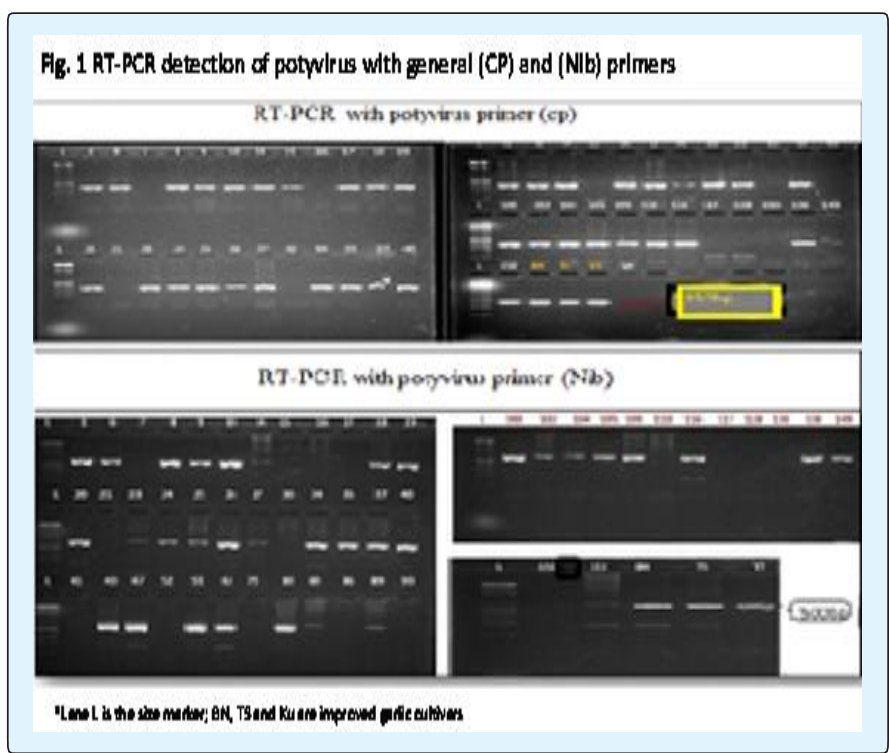

Specific primers for garlic virus-b, garlic virus-c and garlic virus-d successfully amplified the expected coat protein gene size of 200bp, 300bp and 200bp representing the viruses respectively (Figure 2).

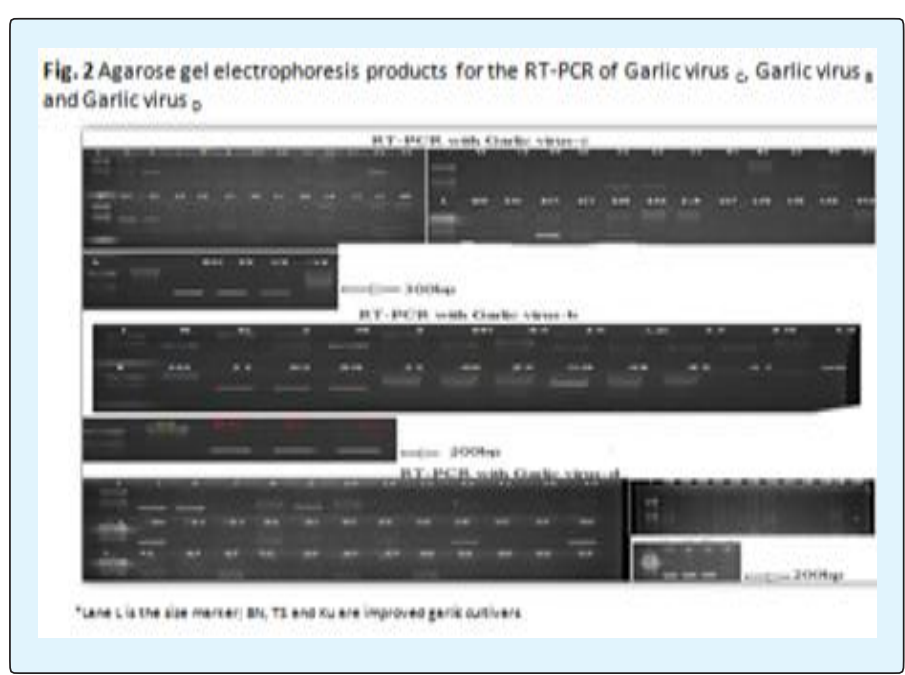

No amplified product was observed for those which are not infected with these viruses. The RT-PCR diagnosis indicated that $85 \%$ and $80 \%$ of the garlic samples were infected by potyviruses using two sets of general primers viz. cp and Nib respectively. The result clearly indicated that potyviruses are the most sever across all garlic producing regions. According to [6] Onion yellow dwarf virus (OYDV), Leek yellow stripe virus (LYSV) is the most common important viruses from potyvirus. From the result we can deduce that the two assays efficiently identified positive samples either infected by OYDV or LYSV. Moreover, three allexiviruses Garic virus-B $\left(\mathrm{GV}_{\mathrm{b}}\right)$, Garlic virus-C $\left(\mathrm{GV}_{\mathrm{c}}\right)$ and Garlic virus-D $\left(\mathrm{GV}_{\mathrm{d}}\right)$ had been identified. The incidence of the viruses was $56 \%, 31 \%$ and $31 \%$ respectively (Figure 3 ).

Fil. 1 incidence garlic wrutes acrosu all tested umples in Ethiopia

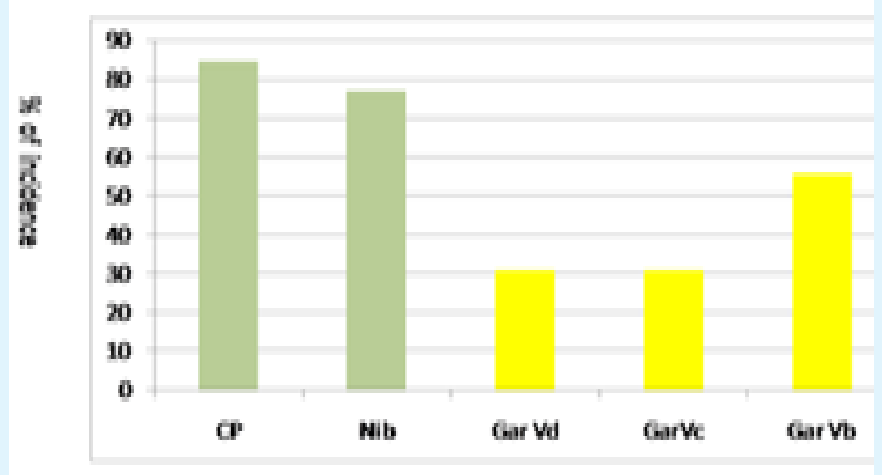

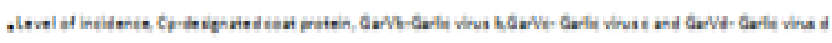




\section{Open Access Journal of Agricultural Research}

Garlic virus $b$ is the most sever among allexiviruses across tested location. Co infection was observed in all tested cites which is very devastating in quantity and quality based on results from many experiment other countries. This study showed that potyviruses are the most prevalent and commonly detected viruses followed by garlic virus c. In all tested samples co infection of potyvirus and allexivirus had been observed. Similar result had been reported by [12]. In addition, [13] stated that infection of potyviruses in garlic was more frequent than carlaviruses because of effective transmission of the viruses by aphids. Moreover, findings in different parts of the world suggested that co infection of garlic from potyvirus, allexivirus and carlaviruses had been frequently exhibited $[8,14,5]$.

Study by Conci et al. [3] showed that co infection of virus on garlic reduces yield and quality by $50-70 \%$. Based on the current result, we can deduce that considerable loss in terms of yield and quality might be happened in Ethiopian garlic production. In this study, all the three improved garlic cultivars (Bishoftu Nech, Tseday and Kuriftu) collected from different parts of the country, were totally infected by the viruses. According to Conci V, et al. [8] correct identification of viruses in mixed complex is very important for taxonomy, epidemiology which intern helps for development of diagnostic and elimination of the viruses.

\section{Conclusion}

The primers used for this study were designed to amplify coat protein (CP) and nuclear inclusion protein $(\mathrm{Nib})$ genes of potyvirus and coat protein (CP) gene of allexiviruses from deep sequencing of infected Ethiopian garlic samples. The assay was found to be effective and efficient which could be used for frequent diagnosis in Ethiopia. In this study, potyvirus were widely distributed across garlic growing parts of Ethiopia either through the infected improved cultivars or through frequent use local accessions. The result of this study showed that the three improved garlic cultivars were totally infected by the viruses. Ultimately, Whole information will be transferred and applied to garlic production system in Ethiopia to establish virus free garlic dissemination scheme.

\section{References}

1. Keller ER, Senula A (2013) Micropropagation and cryopreservation of garlic (Allium sativum L.). Methods Mol Biol 11013: 353-68.

2. Martin, Paul VD, Peter MA, Vanwell (1995) Efficiency of eradication of four viruses from garlic (Allium sativum) by meristem-tip culture. European Journal of Plant Pathology 101(3): 231-239.

3. Conci VC, Canavelli A, Lunello P, Rienzo Di, Nome SF, et al. (2003) Yield losses associated with virusinfected garlic plants during five successive years. Plant Dis 87: 1411-1415.

4. Taskin H, Baktemur G, Kurul M, Buyukalaca S (2013) Use of tissue culture techniques for producing virus free plant in garlic and their identification through Real-Time PCR. Scientific World Journal. PMC3725790.

5. Parrano L, Afunian M, Pagliacca D, Douhan G, Vidalakis G (2012) Characterization of viruses associated with garlic plants propagated from different reproductive tissue from Italy and other geographic regions. Phytopathologia Mediterranea 51(3): 549-565.

6. Takaichi M, Yamamoto M, Nagakubo T, Oeda K (1998) Four garlic viruses identified by reverse transcription-polymerase chain reaction and their regional distribution in northern Japan. Plant Disease 82: 694-698.

7. Oliveira ML, Marchi BR, Mituti T, Pavan MA, KrauseSakate R (2014) Identification and sequence analysis of five allexiviruses species infecting garlic crops in Brazil. Trop Plant Pathology 39(6): S198256762014000600011.

8. Conci V, Nome SF, Milne RG (1992) Filamentous viruses of garlic in Argentina. Plant Disease 76: 594596. 


\section{Open Access Journal of Agricultural Research}

9. Betewulign EA, Taddesse ST (2014) Evaluating the role of Nitrogen and Phosphorous on the growth performance of garlic (Allium sativum L.). Asian Journal of Agricultural Research 8(4): 211-217.

10. Worku Y, Dejene M (2012) Effects of garlic Rust (Puccinia allii) on Yield and Yield Components of garlic in Bale highlands, South Eastern Ethiopia. Journal of Plant Microbiology 3: 118.

11. Kero J (2010) Survey and Serological identification of viruses infecting Garlic (Allium sativum L.) in Ethiopia. A Thesis submitted to School of graduate studies Addis Ababa University in Paritial fulfilment of Master Degree in Biotechnology.
12. Klukackova J, Navratil M, Duchoslav M (2007) Natural infection of garlic (Allium sativum L.) by viruses in the Czech Republic. Journal of plant diseases and protection 114(3): 97-100.

13. Melo FP, Nagata T, Dusi AN, Busso JA, Torres AC, et al. (2004) Detection of three Allexivirus species infecting garlic in Brazil. Presq agropec Brasilia 39(8): 735740 .

14. Ahmed MS, Sabry YM Mahmoud, Dawood RA (2012) Molecular Characterization of Onion Yellow Dwarf Virus (Garlic Isolate) with Production of Virus-free Plantlets. International Journal of Virology 8(1): 6170. 